\title{
Enhancing Effective Utilization of Aid in Fragile States
}

\author{
Sanjeev Gupta*
}

February 2008

\begin{abstract}
This paper explores the macroeconomic implications of aid flows in countries with weak institutions. It argues that these countries should take into account their overall macroeconomic position, their capacity to absorb aid at the sectoral and subnational levels, and the strength of their fiscal institutions in deciding how much and how fast to spend aid. These considerations may warrant a gradual use of aid, except when aid is provided for humanitarian purposes. There is some basis for frontloading spending for countries emerging from a conflict, otherwise fragile states should seek to smoothen their spending against the background of aid volatility and uncertainty.
\end{abstract}

Keywords: aid absorption, aid flows, institutions, post-conflict

JEL classification: F35, O19, O11

Copyright (C) UNU-WIDER 2008

* Fiscal Affairs Department, International Monetary Fund, Washington, DC: email: sgupta@imf.org

This is a revised version of a paper originally prepared for the UNU-WIDER conference on Fragile States-Fragile Groups, directed by Mark McGillivray and Wim Naudé. The conference was jointly organized by UNU-WIDER and UN-DESA, with a financial contribution from the Finnish Ministry for Foreign Affairs.

UNU-WIDER gratefully acknowledges the contributions to its project on Fragility and Development from the Australian Agency for International Development (AusAID), the Finnish Ministry for Foreign Affairs, and the UK Department for International Development-DFID. Programme contributions are also received from the governments of Denmark (Royal Ministry of Foreign Affairs), Norway (Royal Ministry of Foreign Affairs) and Sweden (Swedish International Development Cooperation AgencySida). 


\section{Acknowledgements}

I wish to thank Richard Allen, Shamsudddin Tareq, Menachem Katz and Marijn Verhoeven for helpful comments on an earlier draft. The views expressed in this paper are solely those of the author and do not necessarily represent those of the IMF or IMF policy.

\section{Acronyms}

$\begin{array}{ll}\text { AAPs } & \text { assessment and action plans } \\ \text { CPIA } & \text { country policy and institutional assessment } \\ \text { CVI } & \text { country vulnerability index } \\ \text { HDI } & \text { human development index } \\ \text { HIPCs } & \text { highly indebted poor countries } \\ \text { LICs } & \text { low-income countries } \\ \text { MDGs } & \text { Millennium Development Goals } \\ \text { PEFA } & \text { public expenditure and financial accountability } \\ \text { PFM } & \text { public financial management systems } \\ \text { ROSC } & \text { World Bank/IMF assessment of the reports on the observance } \\ & \text { of standards and codes }\end{array}$

The World Institute for Development Economics Research (WIDER) was established by the United Nations University (UNU) as its first research and training centre and started work in Helsinki, Finland in 1985. The Institute undertakes applied research and policy analysis on structural changes affecting the developing and transitional economies, provides a forum for the advocacy of policies leading to robust, equitable and environmentally sustainable growth, and promotes capacity strengthening and training in the field of economic and social policy making. Work is carried out by staff researchers and visiting scholars in Helsinki and through networks of collaborating scholars and institutions around the world.

www.wider.unu.edu

publications@wider.unu.edu

UNU World Institute for Development Economics Research (UNU-WIDER)

Katajanokanlaituri 6 B, 00160 Helsinki, Finland

Typescript prepared by Liisa Roponen at UNU-WIDER

The views expressed in this publication are those of the author(s). Publication does not imply endorsement by the Institute or the United Nations University, nor by the programme/project sponsors, of any of the views expressed. 


\section{Introduction}

In recent years, there has been much discussion on the macroeconomic consequences of the scaling up of aid in low-income countries (LICs) (Aiyar, Berg and Hussain 2005; Foster and Killick 2006; Gupta, Powell and Yang 2006; Berg et al. 2007). The debate has centred on whether aid surges experienced since the late 1990s have been absorbed or spent, and on the nature of the macroeconomic and structural policies needed in aidreceiving countries so that they can use aid effectively. 1 The results from these studies show that many countries did not fully absorb or spend the aid. A recent study estimated that aid-receiving countries in Sub-Saharan Africa spent between 30 and 80 per cent of aid, depending on the macroeconomic conditions and level of reserves. The proportion of spending was more when inflation was less than 5-7 per cent.2

The literature on aid spending and absorption in fragile states is limited. These states comprise countries recovering from conflict and those classified as having weak institutions and policies. 3 A recent paper (Elbadawi, Kaltani and Schmidt-Hebbel 2007) shows that while post-conflict countries receive substantial aid flows after the onset of peace, the flows are not well synchronized with country capacity to absorb them. The aid tends to surge immediately after the cessation of hostilities and gradually taper off thereafter. Collier and Hoeffler (2002) argue that this pattern of aid flows is often not optimal, as the capacity of these countries to absorb assistance is rather low in the early post-conflict period. Elbadawi, Kaltani and Schmidt-Hebbel results indicate that many post-conflict countries did not spend the full amount of aid-akin to the response of other aid-receiving countries.

This paper further explores the macroeconomic implications of aid flows in countries with weak institutions. In doing so, it lists considerations that are relevant for policymakers in these countries for promoting effective aid utilization. The paper is organized as follows: section 2 discusses the macroeconomic implications of aid flows for LICs in general and for post-conflict countries specifically. Considerations bearing on the spend/save decision in countries with macroeconomic imbalances and weak institutions

1 Aid absorption is defined as the extent to which a country's non-aid current account deficit widens in response to an increase in aid inflows. This captures the quantity of net imports financed by the increased aid and represents the additional transfer of real resources enabled by the aid. Aid spending is defined as the widening in the government fiscal deficit (net of aid) that accompanies an increase in aid.

2 See Independent Evaluation Office (2007).

3 The definition of a fragile state varies. The World Bank defines fragile states as those countries with a country policy and institutional assessment (CPIA) of 3.2 or less (World Bank, 2007). There are 29 such countries, plus a few others that do not have a CPIA rating (e.g., Afghanistan and Somalia). The African Development Bank has used two criteria for its definition: It defines fragile states as those with a CPIA of less than 3 or by the Country Vulnerability Index (CVI) of less than 0.351. The latter is a weighted index of various measures of vulnerability, which combine selected aggregates from CPIA, the United Nations Development Programme (UNDP) Human Development Index (HDI) and other sources of vulnerability such as external shocks (oil price increases), high dependence on primary commodities and exposure to frequent natural disasters. Core fragile states are those whose fragility is captured by both the CPIA and the CVI; they number twelve. The African Development Bank is in the process of revising its methodology to include other criteria such as: (i) countries in post-crisis/post-conflict transition; (ii) those at the bottom of the UN Human Development Index (as before); and (iii) those that have had their per capita GDP contract by more than 10 per cent in real terms since 1990 (base year of the Millennium Development Goals-MDGs) to 2005. 
are presented in section 3. Section 4 discusses the merits of frontloading and expenditure smoothing approaches for fragile states. The paper concludes in section 5.

\section{Macroeconomic implications of aid flows}

Aid augments domestic resources, but it can have implications for the real exchange rate, exports, and competitiveness, including in countries with weak institutions. In practice, however, macroeconomic impact of aid depends both on how a country's policies (e.g., monetary, fiscal and exchange rate) respond to aid inflows and how it spends the additional resources (e.g., traded or nontraded goods). The former can be analysed in terms of absorb and spend framework discussed below (Aiyar, Berg and Hussain 2005; Berg et al. 2007).

\subsection{Absorb and spend framework}

One could conceive of four basic combinations of absorption and spending in response to aid inflows, although intermediate combinations are also feasible. Each one has different macroeconomic implications (see Table 1). The central bank controls absorption through two mechanisms: (i) by deciding how much of the foreign exchange associated with aid it should sell; and (ii) through its interest rate, which impacts on aggregate demand. The government has to decide how much of the local currency counterpart it should spend in its budget.

Aid is absorbed and spent (top left quadrant)

The government spends the aid, and the central bank sells the foreign exchange. The current account widens by the amount of aid received, and the fiscal deficit is fully financed by higher aid. This is the outcome that most donors and international partners are striving for in aid-receiving countries. In this instance, some real exchange rate appreciation may be appropriate to effect reallocation of resources from the traded to the nontraded sector, for example, social services. Studies show that neither LICs nor the post-conflict countries that experienced aid surges in recent years fully absorbed and spent incremental aid.

Aid is neither absorbed nor spent (top right quadrant)

In this instance, the countries simply save the entire aid by building up their international reserves. The fiscal deficit does not increase. This strategy was adopted by some countries (e.g., Ethiopia and Ghana) in the short term to increase foreign exchange reserves from a low level-a consideration that is of relevance to countries emerging from a conflict. This may also be an appropriate response to smooth spending over time if aid flows are viewed as highly volatile (e.g., Ghana).

Aid is absorbed but not spent (bottom left quadrant)

Increased aid flows substitute for domestic financing of the government deficit. The sale of foreign exchange draws liquidity out of the economy and lowers inflation. As reported by Elbadawi, Kaltani and Schmidt-Hebbel, post-conflict countries partially followed this approach to reduce the level of public debt and crowd in the private sector. The receipts from the sale of foreign exchange were used to retire government debt in these countries. 
Aid is spent but not absorbed (bottom right quadrant)

In this case, the fiscal deficit widens in response to higher aid flows, but the central bank does not sell the foreign exchange to finance additional imports. This is tantamount to financing government deficit by printing money or borrowing from the domestic private sector, for example, by selling treasury bills. This results in a substantial increase in domestic interest rates, thereby crowding out the private sector. In a way, this reflects inadequate coordination between the ministry of finance and the central bank. Some aidreceiving countries (e.g., Tanzania and Uganda) followed this approach in response to recent aid surges.

Table 1

\section{Aid is absorbed and spent}

The government spends the aid.

The central bank sells the foreign exchange. The current account deficit widens.

\section{Aid is absorbed but not spent}

Government expenditures are not increased. The central bank sells the foreign exchange. Monetary growth is slowed; nominal exchange rates appreciate; inflation is lower.

\section{Aid is neither absorbed nor spent}

Government expenditures are not increased.

Taxes are not lowered.

International reserves are built up.

\section{Aid is spent but not absorbed}

The fiscal deficit widens (expenditures are increased). The central bank does not sell foreign exchange. International reserves are built up. Inflation increases.

Source: Gupta, Powell and Yang (2006).

\subsection{Post-conflict experience}

Elbadawi, Kaltani and Schmidt-Hebbel (2007) report that post-conflict countries saved part of the aid. Because central banks in these countries did not sell all their foreign exchange acquired through aid, there was no significant real appreciation of the exchange rate. The aid literature discusses at length the adverse effects of real exchange rate appreciation on the tradable goods sector-that is, the so-called Dutch disease effect. Rajan and Subramanian (2005) argue that real exchange rate effects on export can be significant, as export-oriented, labour-intensive industries grow more slowly than other industries. These effects are stronger when trade is restricted and when the economy is running at full capacity.

How aid resources are deployed in post-conflict countries or fragile states in general has a bearing on the real exchange rate. If aid is used for productivity-enhancing projects, such as restoring and building critical infrastructure to boost the economy's supply capacity and alleviating constraints to growth, the pressure on the real exchange rate is likely to be mitigated. This is also likely when much of the aid is spent on importables. On the other hand, if aid finances social sector spending, which includes more nontraded goods, the macroeconomic consequences will likely be exacerbated.

Estimation of the equilibrium real exchange rate for such countries on the basis of historical data may not provide useful guidance, particularly when the potential for aid inflows is large. As noted earlier, some real exchange rate adjustment may be necessary and, indeed, appropriate in response to the higher level of aid to facilitate resource reallocation in favour of the nontraded sector. Elbadawi, Kaltani and Schmidt-Hebbel (2007) find that the median post-conflict country suffered from moderate real exchange rate overvaluation after the start of peace, but this could not be traced to aid flows. This 
does not imply that the policymakers in these countries can afford to overlook appreciation in the real exchange rate; rather, they should remain alert to this possibility and ensure that appropriate policy actions are taken to offset its adverse consequences.

The empirical evidence from post-conflict countries suggests that a sound fiscal policy (including appropriate expenditure composition) through its positive effects on growth can mitigate the pressure on the real exchange rate. For example, conflict raises the share of defence spending in total government expenditure, which in turn has a negative effect on growth by diverting resources away from the spending on sectors (education, health, infrastructure) that promote economic growth over the long term (Gupta et al. 2004). Elbadawi, Kaltani and Schmidt-Hebbel (2007) find that in post-conflict countries financial development and deepening as well as trade openness alleviate constraints to growth, thereby diminishing the adverse impact of real exchange rate appreciation. 4 They also find evidence that the maximum growth impact of aid is during 6-9 years after the start of peace. This suggests that saving part of the aid received during the initial years is perhaps appropriate.

It is unclear how good the coordination between the fiscal and monetary authorities has been in post-conflict countries during periods of aid surges. Insufficient coordination could partly explain why aid was not fully absorbed. The central bank may have targeted a reserve buildup, sought to prevent an appreciation of the exchange rate, decided to use receipts from the sale of the foreign exchange to retire government debt, or some combination of the three. As saved-up aid is spent, coordination between the two authorities becomes critical; the central bank must sell foreign exchange as the ministry of finance expands spending in the budget by the amount of saved aid. The objective is to ensure that the central bank takes into account the impact of the ministry of finance's fiscal operations. This coordination between the monetary and fiscal policies is relevant whether the country has fixed or flexible exchange rates. 5

\section{Considerations determining spend/save decision in fragile states}

In deciding how much and how fast they should spend aid, policymakers in fragile states have to be aware of the country's overall macroeconomic position, its capacity to absorb aid at the sectoral and subnational levels, and the strength of its institutions. The impact of these flows on debt sustainability and growth is also critical. Of course, these considerations do not apply to humanitarian aid, which should be spent as soon as it is received.

\subsection{Overall macroeconomic conditions}

Overall macroeconomic conditions affect the amount of aid that could be spent immediately. This point is illustrated first with data from selected post-conflict countries and then followed up by a comparison of fragile states with that of LICs in general. For

\footnotetext{
4 Addison, Chowdhury and Murshed (2002) find that conflicts have a negative effect on financial development and overall financial depth.

5 See Heller et al. (2006) for details.
} 
instance, large macroeconomic imbalances (e.g., a high rate of inflation and a low level of reserves) at the end of conflict may require a more gradual increase in aid-financed spending. Figures 1 through 5 give an indication of the macroeconomic conditions prevailing around the end of the conflict. 6 On average, real GDP falls significantly during the conflict, which is consistent with earlier studies on the economic consequences of conflict (Collier 1999; Collier et al. 2003). 7 The figures further show that the average inflation is high, reflecting a relatively high domestic (including bank) financing of the government deficit. At the same time, revenues are lower owing to the decline in economic activity; however, the reduction in the overall spending is not sufficient to offset the revenue drop. The level of foreign exchange reserves is also lower than before the conflict. In such circumstances, further pressures on domestic demand are likely to aggravate macroeconomic imbalances, although as noted above, how the aid is spent is crucial. 8

During the conflict, some revenue loss is recouped by seigniorage generated by bank financing of the government deficit. However, the scope for seigniorage revenue is determined by the willingness of the population to hold money balances in local currency vis-à-vis foreign currencies. Post-conflict aid displaces domestic financing of the budget. It restores confidence in the local currency by curbing capital flight, and reduces reliance on seigniorage as a revenue source (Adam, Collier and Davies 2007; Davies 2007).9 Aid thus contributes to 'monetary reconstruction'. This effect is reinforced by rising money demand stemming from output growth made possible by aid, although Adam, Collier, and Davies find that income elasticity of the demand for money is still significantly lower than in normal times. Under such circumstances, unrestrained inflation after the hostilities have ceased would discourage the population from holding money balances in local currency, and not contribute to 'monetary reconstruction' of the economy. High and sustained inflation would also not help stem and reverse capital flight.10

Although macroeconomic indicators of fragile states (as defined by the World Bank) are as poor as those of countries emerging from a conflict, they are nevertheless weaker than those found in LICs in general. Both GDP growth and the level of foreign exchange reserves are lower and inflation higher in fragile states than in other LICs.

6 These data are compiled for a number of countries that went through a conflict situation using an 'eventstudy' methodology and where the IMF was involved in rebuilding fiscal institutions after cessation of the conflict. That is, data are transformed from calendar time into 'event time'. However, caution is required in interpreting the results because the effect of other influences is not controlled for and the results are not compared with a control group of countries.

7 Collier (1999) finds that, relative to the counterfactual of peace, the marginal effect of a conflict causes per capita GDP to decline by 2 per cent per annum during the war.

8 A recent study on Sub-Saharan African countries (Independent Evaluation Office 2007) finds that a large proportion of incremental aid (over 80 per cent) was used for retiring domestic debt when inflation exceeded 5 per cent.

9 According to Adam, Collier and Davies, a one percentage point of GDP increase in aid reduces seignorage by one third of a per cent of GDP.

10 Post-conflict inflation increases annual capital flight by up to 0.01 per cent of GDP (Davies 2007). This effect is substantial at high inflation rates. 
Figure 1

Growth

in selected post-conflict countries (annual \% change)
Figure 2

Consumer price inflation in selected post-conflict countries (annual \% change)

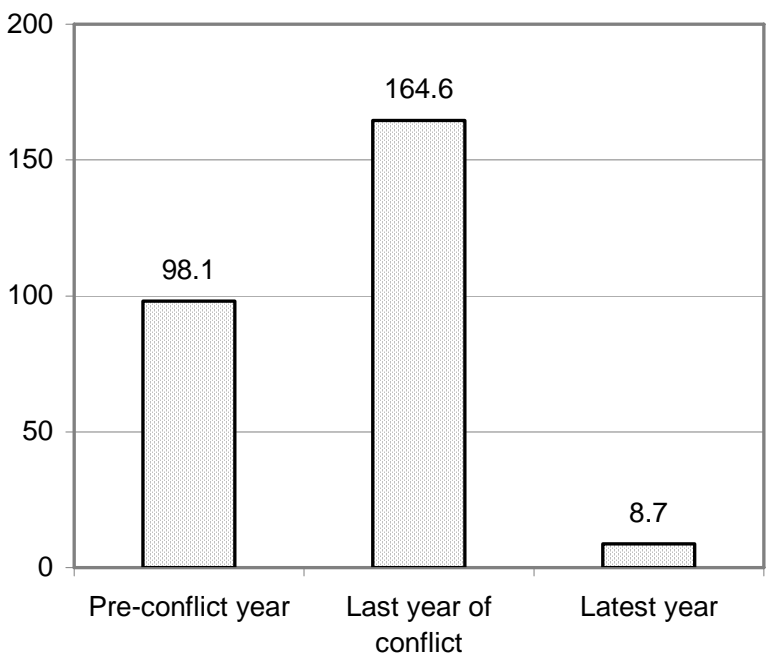

Note: Based on a sample of 11 countries: Afghanistan, Albania Cambodia, Dem. Rep. of Congo, Croatia, Lebanon, Mozambique, Rwanda, Sierra Leone, Tajikistan and Yemen

Lebanon, Liberia, Mozambique, Rwanda, Serbia and

Montenegro, Sierra Leone, Tajikistan and Yemen

'Pre-conflict' refers to the year before the conflict;

'Last year of conflict' refers to the year before the first technical assistance mission by the IMF's Fiscal Affairs Department, either during or immediately following the conflict;

'Latest year' refers to the most recent year for which data are available.

Source (for Figures 1 and 2): IMF (WEO database, April 2004 and April 2007); World Bank (WDI database).

Figure 3

Fiscal aggregates

in selected post-conflict countries (in \% of GDP)

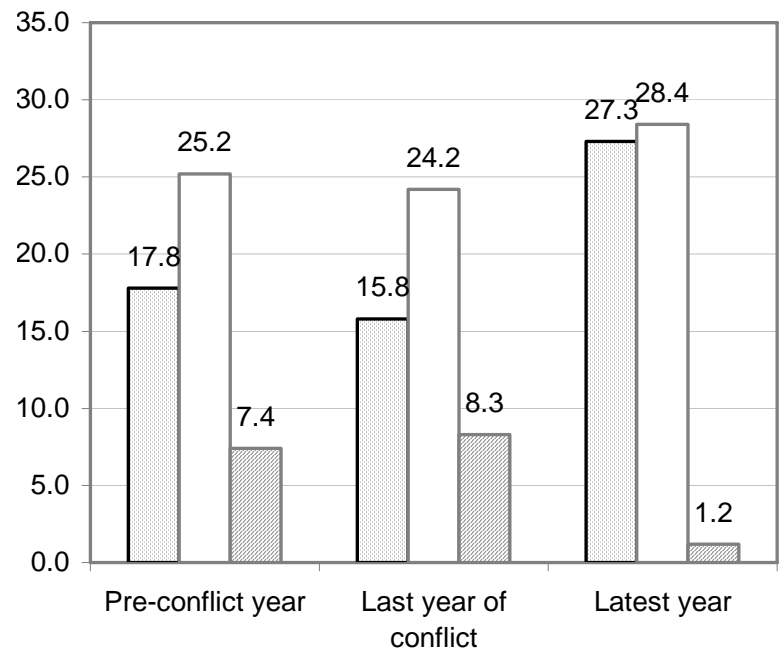

口Total revenue \& grants

$\square$ Total expenditure \& net lending

口 Overall deficit

Note: Based on a sample of 10 countries: Albania, Cambodia, Democratic Republic of Congo, Croatia, Lebanon,

Mozambique, Rwanda, Sierra Leone, Tajikistan and Yemen

Notes and sources for Figures 3 and 4: as given in Figure 1.
Figure 4

Financing of the budget

in selected post-conflict countries (in \% of GDP)

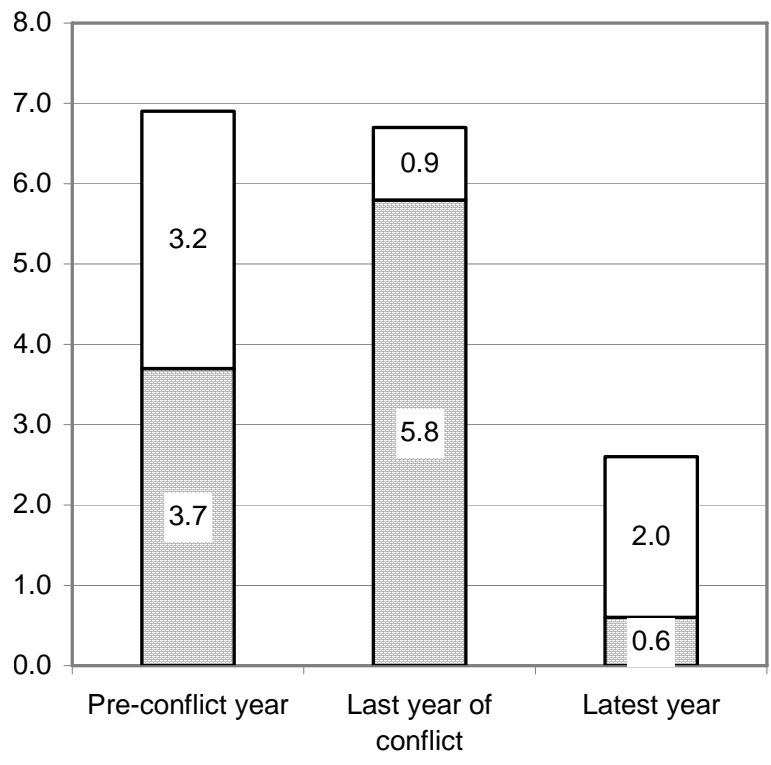

口Domestic financing $\square$ Net foreign financing

Note: Based on a sample of 9 countries: Albania, Cambodia, Democratic Republic of Congo, Lebanon, Mozambique, Rwanda, Sierra Leone, Tajikistan and Yemen 
Figure 5

Reserves in selected post-conflict countries (in months of imports of goods, average) 10.0

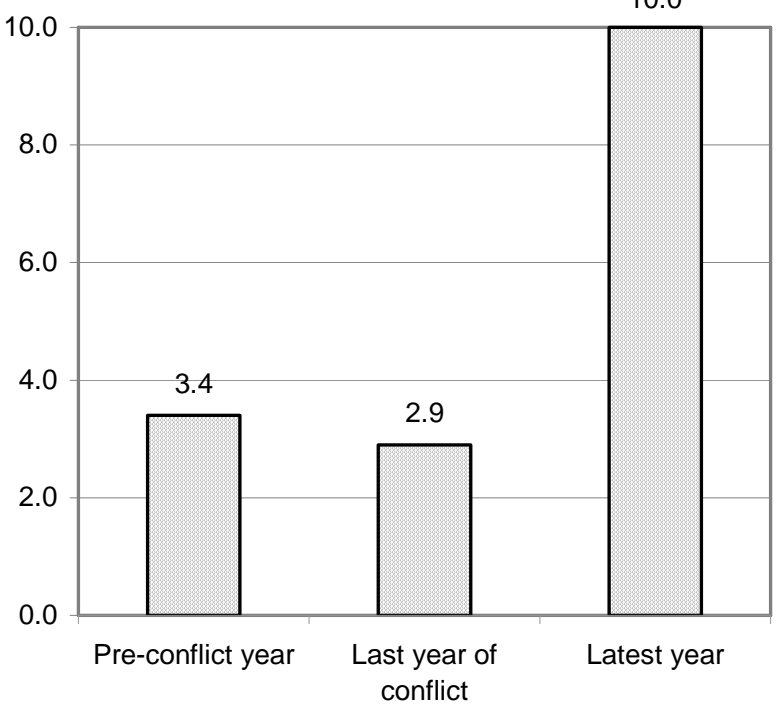

Note: Includes Albania, Dem. Rep. of Congo, Croatia, Lebanon, Mozambique, Rwanda, Sierra Leone, Yemen.

Pre-conflict years adjusted to one year before the conflict.

Sources for Figures 5 and 6: IMF 2007 (WEO, April).

Figure 7

Consumer price inflation in selected fragile states \& other LICs (annual \% change, average)

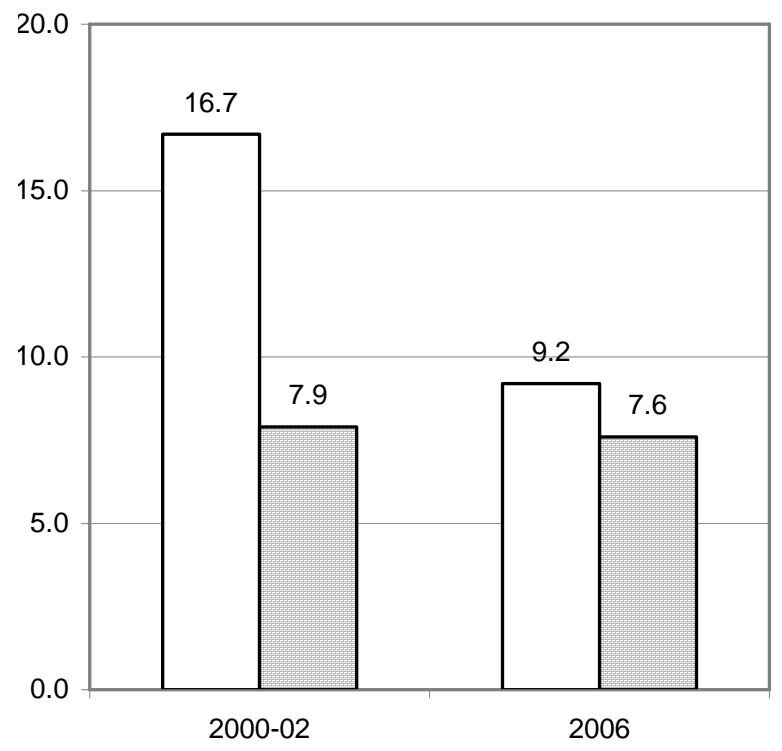

口Fragile states $\square$ Other LICs

Notes and sources for Figures 7 and 8: as given in Figure 5.
Figure 6

Real GDP growth in selected fragile states \& other LICs (annual \% change, average)

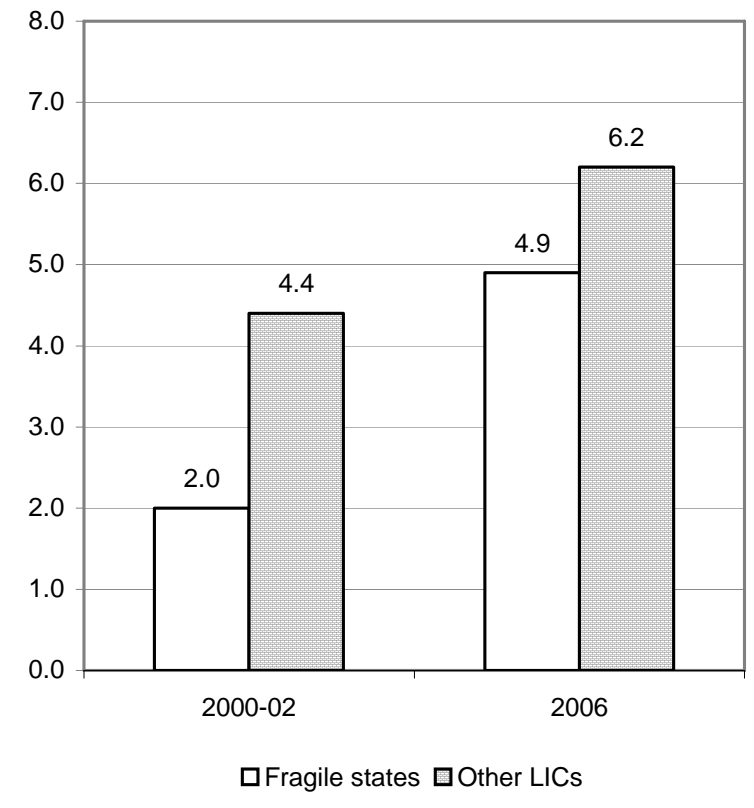

Note: 'Fragile states' include Angola, Burundi, Central African Rep., Chad, Comoros, Republic of Congo, Côte d'Ivoire, Djibouti, Eritrea, Gambia, Guinea, Guinea-Bissau, Haiti, Lao People's Dem. Rep., Mauritania, Myanmar, Nigeria, Papua New Guinea, São Tomé \& Principe, Solomon Is. Sudan, Togo, Tongo, Uzbekistan, Vanuatua and Zimbabwe. 'Other LICs' include Bangladesh, Benin, Bhutan, Burkina Faso, Ethiopia, Ghana, India, Kenya, Kyrgyz Republic, Madagascar, Malawi, Mali, Mongolia, Mozambique, Nepal, Niger, Pakistan, Rwanda, Senegal, Tajikistan, Tanzania, Uganda, Vietnam, Yemen and Zambia.

Figure 8

Reserves in selected fragile states \& other LICs (in months of imports of goods, average)

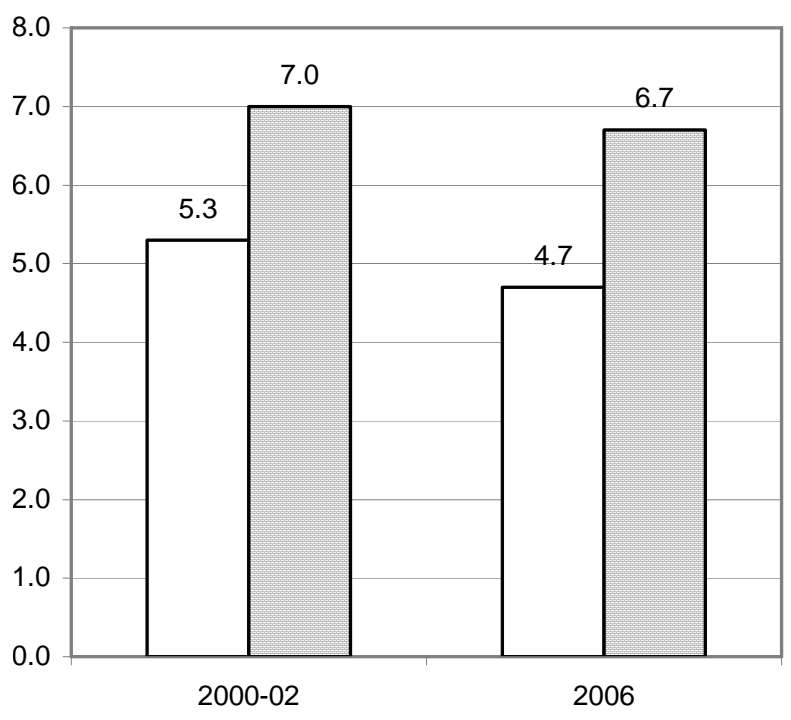

$\square$ Fragile states $\square$ Other LICs 


\subsection{Sectoral absorptive capacity}

Another consideration is the capacity of different sectors to utilize aid-financed spending. According to Collier (1999), conflicts affect the economy in different ways. Besides diverting spending from productive sectors such as education and health and infrastructure, they destroy physical assets in the economy. That is, the conflict causes a destruction of basic infrastructure including schools, health centres and hospitals. While using aid to rebuild and rehabilitate these assets is an effective use of resources, this effort is likely to be constrained by the lack of trained manpower. A large segment of the skilled population (e.g., teachers and doctors) may have been lost to the conflict or displaced as a result of the conflict. In addition, the conflict may have created a 'lost generation' of relatively unskilled young population resulting from disruptions to the education systems. In general, fragile states suffer from skill shortages, which limit their ability to expand aid-financed service provision. These difficulties are more acute at the subnational level where much of the social spending takes place.11

\subsection{Debt sustainability and growth impact of spending}

Debt sustainability is impacted by (i) the borrowing by the country, including from domestic sources; and (ii) sterilization of aid (even grant) flows. When the central bank decides not to sell the foreign exchange acquired through aid and seeks to sterilize the liquidity impact of aid, domestic interest rates could increase significantly, exerting pressure on public debt dynamics. In the same vein, a sudden drop in aid could cause exchange rate to depreciate, thereby increasing the cost of servicing external debt.

The aid-financed spending also affects growth, and thus, debt sustainability. Spending on infrastructure would be expected to promote growth in the short to the medium term, which would strengthen the debt dynamics of the country. What is essential is to prioritize capital projects and choose those that have a relatively high rate of return. Similarly, expanding spending on education and health would enhance labour productivity over time and improve health and education outcomes. To be able to achieve desired outcomes, it is necessary that resources are spent efficiently and fiscal institutions are strong.

\subsection{Institutional capacity}

According to North (1991) 'institutions provide the broad framework of formal and informal rules and constraints that govern the way organizations, as groups of people, function. Formal rules include constitutions and laws. Informal constraints include customs, codes of conduct and sanctions'. Conflicts can damage these institutions covering the social, economic, legal, and political organization of the society. There are at least five types of market-supporting institutions: property rights, regulatory, macroeconomic stabilization, social insurance, and conflict management (Rodrik 2000). These institutions have a strong relationship with growth (Rodrik 2004). The economic institutions influence the ability of the government to effectively conduct macroeconomic management and fiscal operations. Conflicts have been found to

11 The rapid decentralization has increased subnational spending shares quite significantly in recent years; in Nigeria, the share of such spending is over 50 per cent (see IMF 2006). 
significantly weaken the capacity of the central bank and the ministry of finance to formulate and implement sound economic policies. Well-sequenced reforms that take into account country specific considerations are therefore needed to rebuild or strengthen this capacity.

Are fiscal institutions weaker in post-conflict countries than in LICs in general? In recent years, a number of diagnostic exercises have been carried out to assess the quality of fiscal institutions and public financial management (PFM) systems in LICs. These assessments allow a comparison of relevant fiscal institutions in countries defined as fragile by the World Bank with those in other LICs. Data are available from three diagnostic exercises: the HIPC/AAP exercise;12 IMF's fiscal ROSC assessments; 13 and public expenditure and financial accountability (PEFA) assessments. 14

The results are not surprising: the countries classified as fragile generally fare worse than the rest of the LICs. According to the HIPC/AAP exercise for which data are available for five fragile states, the greatest weaknesses are in budget execution, followed by budget reporting. In budget formulation and execution, the PFM systems have worsened over time (Figures 9, 10, and 11). The fiscal ROSCs and PEFA assessments have been completed for only two fragile states. The results, which are broadly similar to those for the HIPC/AAP exercise, should therefore be interpreted with caution. Note that for the two ROSCs in fragile states, there are many zero values, suggesting that PFM in these countries lacks vital elements such as internal and external audit systems. Interestingly, PEFA assessments show that donor practices fare better in fragile states than in other LICs. This benchmark comprises three elements: predictability of direct budget support; financial information provided by the donors for budgeting and reporting on project and programme aid; and the proportion of aid that is managed using national procedures. 15

Given weaknesses in fiscal institutions and the need for funding humanitarian and other operations, there may be a basis for channelling aid to these countries outside the budget in the very short term. However, these flows would need to be fully coordinated with the budget priorities to prevent duplication and waste. Moreover, earmarked aidprovided in part to circumvent institutional weaknesses in these countries-can introduce considerable rigidities in the budget. It restricts governments' choices and prevents them from reallocating spending in response to changing economic circumstances and to sectors consistent with their own priorities. The donors face a dilemma: they would like to spend the aid resources as efficiently as possible in the short term, while striving to build institutions in the medium term.

12 PFM systems of highly indebted poor countries (HIPCs) were assessed jointly by the World Bank and IMF following the granting of debt relief to these countries. Assessment and action plans (AAPs) were prepared by these institutions in consultation with the authorities for 23 countries in 2001 and 26 countries in 2004.

13 Since 1999, 29 LICs have been assessed against the IMF’s code of fiscal transparency.

14 Since its inception in 2005, public expenditure and financial accountability (PEFA), developed jointly by the World Bank, the IMF, the EU, and several other bilateral donors, has assessed 12 LICs.

15 For full information on PEFA indicators, see the PEFA handbook (2005: 50-2). 
Figure 9

HIPC-AAP: Progress in PEMS by key indicator categories

(the number of countries meeting benchmarks in \% of total)

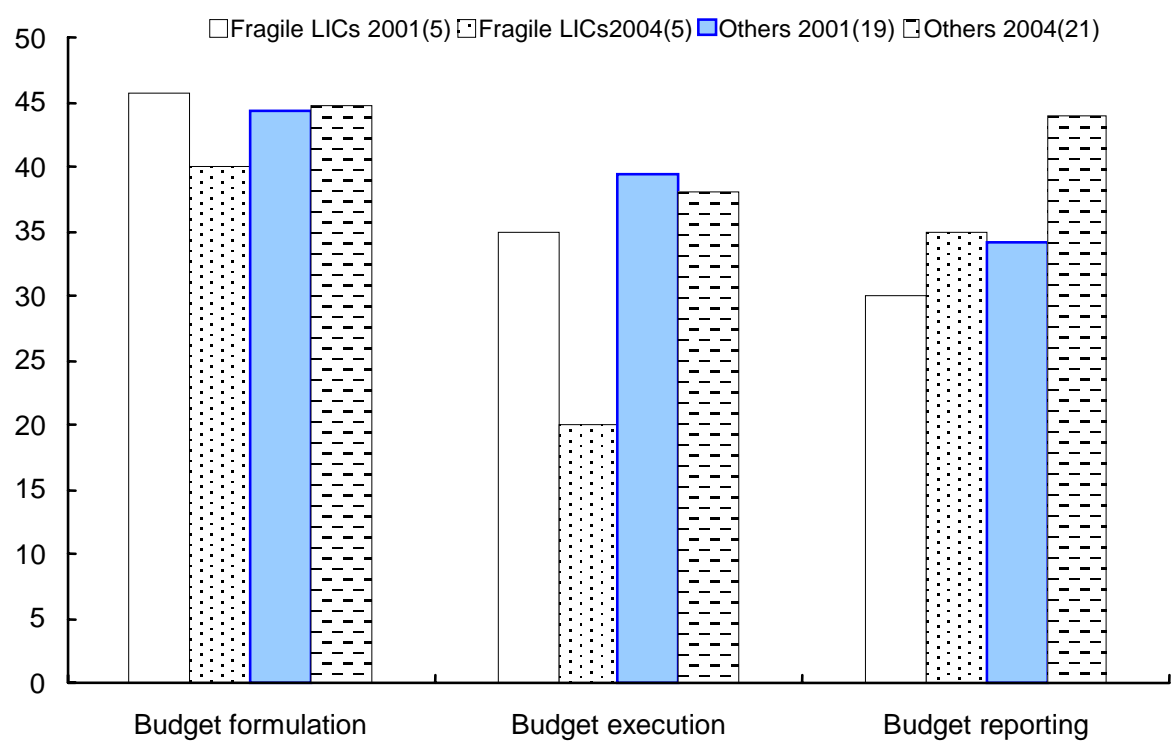

Note: The total numbers of assessed countries in parenthesis.

Source: IMF and World Bank estimates.

Figure 10

Fiscal transparency performance indicators in low-income countries (the share of countries with strong performance in total)

$$
\square \text { Fragile LICs (2) } \quad \square \text { Others (25) }
$$

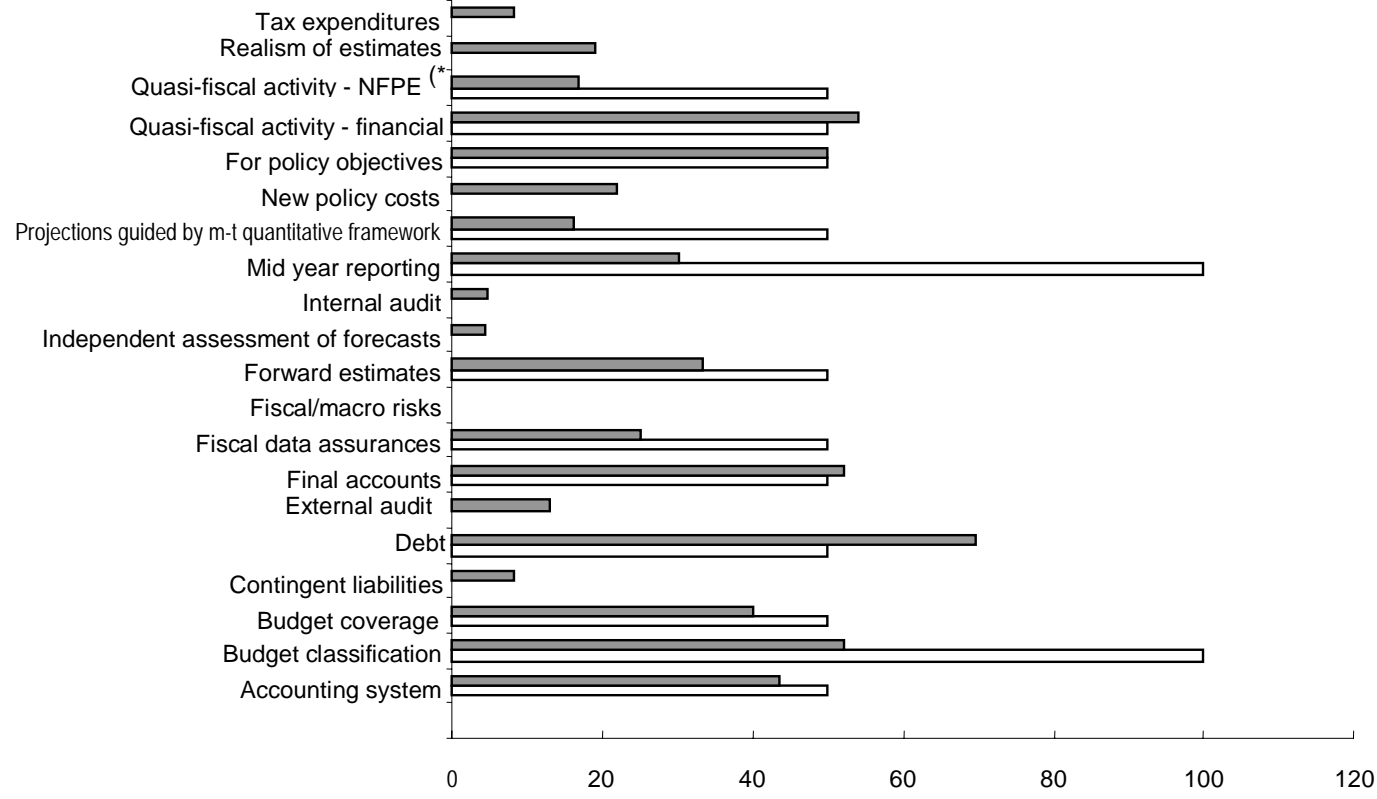

Note: The number of available ROSC reports in 1995-2005 in parenthesis.

$\left(^{*}=\right.$ non-financial public enterprises.

Source: IMF staff estimates based on IMF Fiscal ROSC assessments. 
Figure 11

Aggregate PEFA ratings by indicator categories

(in average aggregate scores: the perfect score $=4$ )

$\square$ Fragile LICs (2) $\quad$ O Others (10)

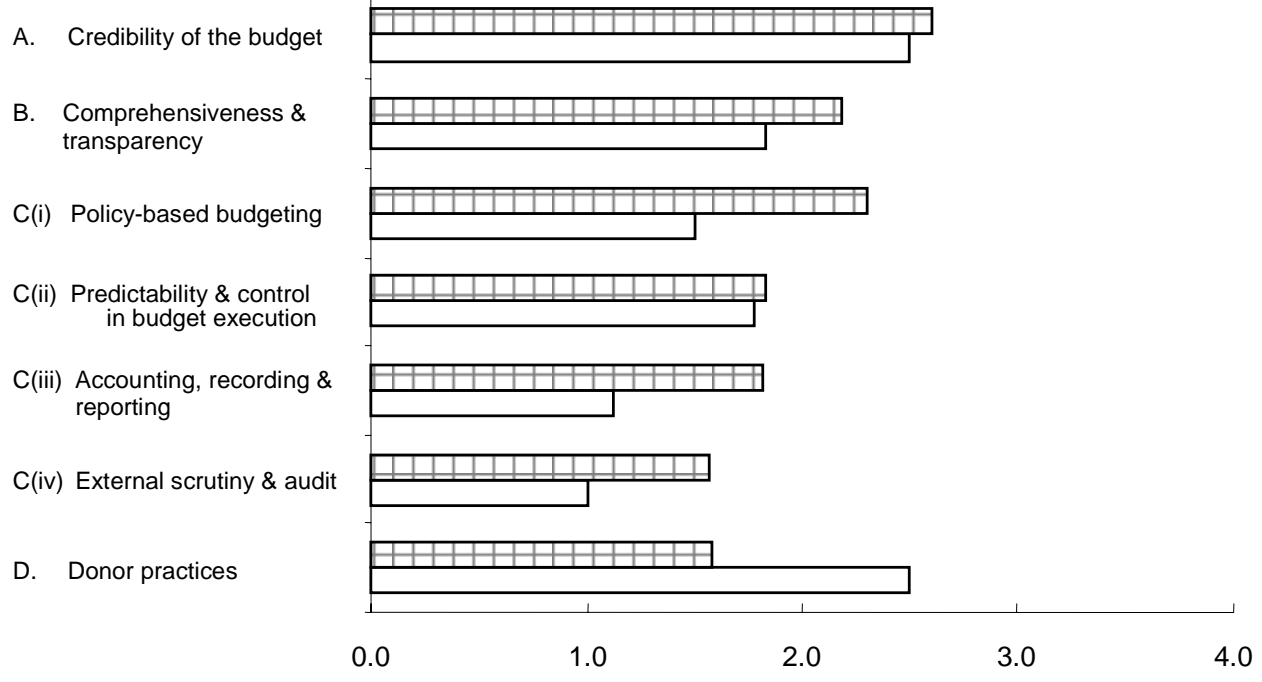

Source: Based on data provided by PEFA Secretariat.

Thus, the decision to spend aid in post-conflict and fragile states may not be constrained by their weak fiscal institutions because of the option to channel aid through extrabudgetary systems. However, if a country continues to receive external resources outside the budget over a sustained period, there is a risk that little effort will be devoted to building fiscal institutions and aligning external flows with resources mobilized domestically. The overall macroeconomic conditions and the economy's absorptive capacity will nevertheless remain relevant in formulating the budget.

Building fiscal institutions in post-conflict countries is a time-consuming process and involves three basic steps (Gupta et al. 2005). These are: (i) ensuring a functioning legal and regulatory framework; 16 (ii) establishing or strengthening the fiscal authority; 17 and (iii) adopting appropriate revenue and expenditure policies and systems. The sequencing of these steps does not have to follow the preceding order; what is implemented first depends on the country's circumstances.

16 The legal and regulatory framework for fiscal operations is derived from the constitution and tax and budget laws. The former usually specifies the division of taxing powers between different levels of government, and between the executive, the legislature, and the judiciary. Tax laws define the power of the tax administration. The purpose of the budget law is to set out budget classifications; provide guidelines on budget execution; establish a consistent framework for internal and external control and audit; and provide mechanisms for financing budget deficits.

17 Strengthening the position of the fiscal authority includes strengthening or establishing a budget department (for coordinating the expenditure programme and preparing fiscal projections and budget execution reports), a treasury department (for controlling spending and ensuring that it is accounted for), and customs and domestic revenue administration departments (for implementing tax policy and collecting tax revenues). 


\subsection{Limits to saving}

Even if the macroeconomic situation is not fully stable and the absorptive capacity of the economy is weak, there are limits to how much aid a country can save. The donors have an interest in seeing that the resources they transfer are in fact used for their intended purposes. At the same time, there are pressures in the aid-receiving country to spend aid to improve economic and social outcomes. Moreover, the scope for saving is circumscribed by the share of project aid in total aid. This aid is already linked to project implementation cycle, and therefore, the aid-receiving country has little discretion on the pace of its utilization. Countries with weak institutions may receive more project aid, in part because donors are reluctant to use the aid-receiving country's own systems to channel external resources.

\section{Frontloading or expenditure smoothing}

As more external resources flow into the country, it must make a key decision on which spending path to adopt. Clearly, this path will be influenced by the country-specific factors and considerations listed above, such as macroeconomic stability and absorptive capacity. One could envisage two options for post-conflict and other fragile states.

Under the frontloaded approach, spending in relation to GDP would increase sharply as resources flow in, and then subside thereafter. This approach would be particularly appropriate for countries emerging from a conflict, where returns to investment in rehabilitating infrastructure are particularly high. Furthermore, there are significant benefits from scaling up spending on providing food and other services to the population affected by the conflict. Resources are also needed to finance demobilization of combatants. However, if frontloading entails domestic borrowing (including from the banking sector), it is likely to exacerbate pressures on domestic prices. Thus, frontloading that is wholly aid-financed would appear to be an appropriate strategy. However, this strategy is not without risks. If frontloaded spending is unproductive and does not contribute to growth, the resulting high spending levels are unlikely to be sustainable over time. This may happen when a country's fiscal institutions are particularly weak, lacking mechanisms to appropriately prioritize spending.

The other option is to keep spending stable as a share of GDP-that is, to smooth it. This may an appropriate strategy for fragile states (other than those emerging from conflict) in the face of aid volatility and uncertainty regarding the future path of aid. The advantage would be that spending would not rise to unsustainable levels owing to temporary aid surges and it would not have to be compressed when there are aid shortfalls. Thus, there will be no disruptions to spending in critical areas (such as provision of drugs for HIV/AIDS prevention and treatment). It would also not exert undue pressure on the country's PFM systems. This may be appropriate also when aid increases are temporary.

Whether the country adopts a frontloaded or expenditure smoothing approach, casting these plans in a medium-term context would help in fiscal planning. The medium-term frameworks go beyond setting the overall spending limits; they also require that countries allocate their annual spending across different sectors and then allocate sectoral spending across different programmes and projects. 
Clearly, fragile states do not have the capacity to formulate these plans in a detailed manner. In fact, their institutions generally have less ability than those of other LICs to develop and/or implement medium-term planning mechanisms. In most LICs, mediumterm frameworks do not exist, and where they do exist, they are not well-integrated into the budget. That implies that fragile states should focus essentially on multi-year macroeconomic scenarios prepared by the countries themselves and their partners. These scenarios should be consistent with fiscal sustainability and macroeconomic stability and the overall expenditure allocations in them should reflect the country's own priorities. The annual budget should then be aligned with the chosen medium-term path. In addition, it is important to ensure that there is a strong relationship between the process for preparing the national plan (e.g., PRSP - the poverty reduction strategy papers), and the budget. Furthermore, proper arrangements should be established between the government and donors for coordinating the management of aid, and, over time, for bringing increasing amounts of aid on budget.

\section{Concluding comments}

The evidence from LICs that experienced aid surges in recent years suggests that these countries saved part of the aid. In this respect, the behaviour of post-conflict countries has not differed radically from that of LICs in general. This paper laid out the macroeconomic and institutional considerations that influence how much and how fast aid post conflict countries and other fragile states should spend. The macroeconomic conditions and institutional capacity are typically weaker in fragile states than in other LICs, providing a good argument for using aid gradually, except for aid provided for humanitarian purposes.

The real challenge is to create conditions in these countries so that all the aid received can be used effectively. Besides ensuring a stable macroeconomic environment that creates the demand for money balances in local currency and prevents capital flight, development partners would need to assist these countries in strengthening their fiscal institutions. This would also allow them to cast their spending plans in a medium-term context as well as contribute to enhancing the efficiency and effectiveness of resource use. Longer-term aid commitments by donors would help in this regard.

There may be some basis for post-conflict countries' frontloading their spending, given the high rates of social return in the aftermath of a conflict. Since the macroeconomic imbalances tend to be severe at this juncture, frontloading should be wholly aid financed. Other fragile states should seek to smoothen their spending against the background of aid volatility and uncertainty. 


\section{References}

Adam, C., P. Collier, and V. Davies (2007). 'Post-Conflict Monetary Reconstruction'. Paper presented at the World Bank Conference on Post-Conflict Transitions, 30 April-1 May, Washington, DC.

Addison, T., A. Chowdhury, and S. M. Murshed (2002). 'By How Much Does Conflict Reduce Financial Development?’. WIDER Discussion Paper 2002/48. Helsinki: UNU-WIDER.

Aiyar, S., A. Berg, and M. Hussain (2005). 'The Macroeconomic Challenge of More Aid'. Finance and Development 42 (3).

Berg, A., S. Aiyar, M. Hussain, S. Roache, T. Mirzoev, and A. Mahone (2007). 'The Macroeconomics of Scaling Up Aid: Lessons from Recent Experience'. IMF Occasional Paper 253. Washington, DC: International Monetary Fund.

Chen, S., N. Loayza, and M. Reynal-Querol (2006). 'The Aftermath of Civil War'. Paper presented at the World Bank Conference on Post-Conflict Transitions, 30 April-1 May, Washington, DC.

Collier, P. (1999). 'On the Economic Consequences of Civil War'. Oxford Economic Papers, 51 (1): 168-83.

Collier, P., and A. Hoeffler (2002). 'Aid, Policy and Growth in Post-Conflict Societies'. WB Policy Research Working Paper 2902. Washington, DC: World Bank.

Collier, P., L. Elliott, H. Hegre, A. Hoeffler, M. Reynal-Querol, and N. Sambanis (2003). Breaking the Conflict Trap, Civil War and Development Policy. WB Policy Research Report. Washington, DC: World Bank.

Davies, V. (2007). 'Capital Flight and War'. Paper presented at the World Bank Conference on Post-Conflict Transitions, 30 April-1 May, Washington, DC.

Elbadawi, I., and K. Schmidt-Hebbel (2007). 'The Demand for Money around the End of Civil Wars'. Paper presented at the World Bank Conference on Post-Conflict Transitions, 30 April-1 May, Washington, DC.

Elbadawi, I., L. Kaltani, and K. Schmidt-Hebbel (2007). 'Post-Conflict Aid, Real Exchange Rate Adjustment, and Catch-up Growth'. Paper presented at the World Bank Conference on Post-Conflict Transitions, 30 April-1 May, Washington, DC.

Foster, M., and T. Killick (2006). 'What Would Doubling Aid Do For Macroeconomic Management in Africa?'. ODI Working Paper 06/26. London: Overseas Development Institute.

Gupta, S., B. Clements, R. Bhattacharya, and S. Chakravarti (2004). 'Fiscal Consequences of Armed Conflict and Terrorism in Low- and Middle-Income Countries'. European Journal of Political Economy, 20 (2): 403-21.

Gupta, S., B. Tareq, B. Clements, A. Segura-Ubiergo, R. Bhattacharya, and T. Mattina (2005). 'Rebuilding Fiscal Institutions in Post-Conflict Countries'. IMF Occasional Paper 247. Washington, DC: International Monetary Fund. 
Gupta, S., R. Powell, and Y. Yang (2006). 'Macroeconomic Challenges of Scaling Up Aid: A Checklist for Practitioners’. IMF Working Paper 05/179. Washington, DC: International Monetary Fund.

Heller, P., M. Katz, X. Debrun, T. Thomas, T. Koranchelian, and I. Adenauer (2006). 'Making Fiscal Space Happen: Managing Fiscal Policy in a World of Scaled-Up Aid’. IMF Working Paper 06/270. Washington, DC: International Monetary Fund.

IMF (2004 and 2007). World Economic Outlook database, April. Washington, DC: International Monetary Fund.

IMF (2006). Regional Economic Outlook, Sub-Saharan Africa. May. Washington, DC: International Monetary Fund.

Independent Evaluation Office (2007). An Evaluation of the IMF and Aid to SubSaharan Africa. Washington, DC: International Monetary Fund.

North, D. (1991). 'Institutions’. Journal of Economic Perspectives, 5 (1): 97-112.

PEFA (2005). PFM Performance Measurement Framework. June. Available at: http://www.pefa.org/PEFA\%20Website\%20--\%20CURRENT\%204-9-03/www.pefa. org\%20WEBSITE/about_test.htm.

Rajan, R., and A. Subramanian (2005). 'What Undermines Aid's Impact on Growth?'. IMF Working Paper 05/126. Washington, DC: International Monetary Fund.

Rodrik, D. (2000). 'Institutions for High-Quality Growth: What They Are and How to Acquire Them’. NBER Working Paper 7540. Cambridge, MA: National Bureau of Economic Research.

Rodrik, D. (2004). 'Getting Institutions Right'. Cambridge, MA: Harvard University. Mimeo. Available at: www//ksghome.harvard.edu/ .drodrik.academic.ksg/ifoinstitutions\%20article\%20_April\%202004_.pdf.

World Bank (nd). World Development Indicators database. Washington, DC: World Bank. 